\title{
KESEJAHTERAAN KEUANGAN KELUARGA USIA PENSIUN: LITERASI KEUANGAN, PERENCANAAN KEUANGAN HARI TUA, DAN KEPEMILIKAN ASET
}

\author{
Nadia Aulia*), Lilik Noor Yuliati, Istiqlaliyah Muflikhati \\ Departemen IImu Keluarga dan Konsumen, Fakultas Ekologi Manusia, Institut Pertanian Bogor, \\ Bogor 16680, Indonesia \\ *)E-mail: nadiaaulia592@gmail.com
}

\begin{abstract}
Abstrak
Penelitian ini bertujuan untuk menganalisis pengaruh literasi keuangan, perencanaan keuangan hari tua, dan kepemilikan aset terhadap kesejahteraan keuangan keluarga usia pensiun. Contoh dalam penelitian ini adalah 120 keluarga dengan responden suami atau istri yang telah memasuki usia pensiun (55-65 tahun). Responden dipilih secara purposive sampling, sebanyak 60 responden di masing-masing wilayah perkotaan dan perdesaan. Penelitian dilakukan di Kota Bandar Lampung sebagai wilayah perkotaan dan Kabupaten Pringsewu sebagai wilayah perdesaan. Data dianalisis menggunakan analisis deskriptif, uji independent sample t-test, dan uji regresi linier berganda. Hasil penelitian menunjukkan bahwa terdapat perbedaan signifikan pada tingkat pendidikan, status bekerja, dan rata-rata pendapatan responden perkotaan dan perdesaan dengan rata-rata capaian di perkotaan lebih tinggi dibandingkan di perdesaan. Rata-rata indeks literasi keuangan dan kesejahteraan keuangan di perdesaan lebih rendah dibandingkan di perkotaan. Persentase kepemilikan perencanaan keuangan hari tua responden di perkotaan lebih tinggi dibandingkan di perdesaan. Rata-rata kepemilikan aset (aset materi dan aset keuangan) lebih banyak di perkotaan dibandingkan di perdesaan. Faktor yang berpengaruh positif signifikan terhadap kesejahteraan keuangan keluarga adalah wilayah, pendidikan, literasi keuangan, perencanaan keuangan hari tua, dan kepemilikan aset.
\end{abstract}

Kata kunci: aset, kesejahteraan keuangan, literasi keuangan, perencanaan keuangan hari tua

\section{Family's Financial Well-Being at Retiress Age: Financial Literacy, Retirement Planning, and Asset Ownership}

\begin{abstract}
This study aims to analyze the effect of financial literacy, retirement planning, and asset ownership on family's financial wellbeing at retirment age. Sample in this research was 120 families with a husband or wife in retiress age (55-65 years old) as a respondent. Respondents were chosen purposively, 60 respondents in each urban and rural area. The research did in Bandar Lampung city as an urban area and Pringsewu district as a rural area. Data were analyzed using descriptive analysis, a independent sample t-test, and multiple linear regression. The result showed that level of education, job status, and average of income were different significant between urban and rural area, and average of the family in urban area was higher than rural area. Index average of financial literacy and financial well-being in rural area was lower than urban area. Percentage of retirement planning ownership of respondent's in urban area was higher than respondents in rural area. Average of asset ownership (material asset and financial asset) also higher in urban than rural area. The factors that have positive significant effect on family's financial wellbeing at retirees age were region, education, financial literacy, and retirement planning.
\end{abstract}

Keyword: asset, financial literacy, financial well-being, retirement planning

\section{PENDAHULUAN}

Masa pensiun menjadi salah satu kondisi yang dikhawatirkan bagi sebagian masyarakat. Hal ini disebabkan masa pensiun merupakan masa perubahan peran, keinginan, pandangan hidup, dan pola hidup bagi setiap individu (Schwartz, 1974; Kubicek et al. 2012; Hershey et al. 2012; Franca 2004). Fase ini juga dapat menimbulkan stres jika tidak dapat melakukan penyesuaian dengan baik. Mukku,
Harbishettar, dan Sivakumar(2018) menemukan bahwa pensiunan di India memiliki self-esteem yang rendah, suasana hati yang cenderung buruk, kesehatan yang menurun, serta merasa tidak aman dengan keuangan yang dimiliki. Sementara itu, menurut Badan Pusat Statistik (2017), orang tua pensiun memiliki indeks kehidupan personal (pendidikan, pekerjaan, pendapatan rumah tangga, kesehatan, dan kondisi rumah) lebih rendah dibandingkan kelompok usia 20- 
40 tahun. Hal tersebut mengindikasikan bahwa masyarakat Indonesia yang memasuki usia pensiun semakin tidak puas dengan kehidupan personal. Hal ini sesuai dengan Garman dan Forgue (1994) yang mengemukakan bahwa masalah yang dihadapi pensiunan adalah pendapatan yang tetap bahkan cenderung menurun serta kesehatan yang memburuk.

Berdasarkan wilayah, indeks kepuasan hidup personal penduduk yang tinggal di wilayah perkotaan memilik indeks yang lebih tinggi $(67,88)$ dibandingkan di perdesaan $(63,72)$ (BPS, 2017). Artinya penduduk di perkotaan merasa lebih puas dengan pendidikan, pekerjaan, pendapatan, kesehatan dan kondisi rumah yang dimiliki dibandingkan penduduk di perdesaan. Sementara itu, berdasarkan Peraturan Pemerintah No. 45 tahun 2015 tentang Penyelenggaraan Program Jaminan Pensiun, usia pensiun dimulai dari usia 56 tahun. Sementara itu, angka harapan hidup rata-rata orang Indonesia pada Tahun 20202025 akan meningkat menjadi 71,5 tahun (BPS, 2017). Kedua kondisi tersebut menggambarkan bahwa kesejahteraan pensiun akan semakin berkurang sehingga penting untuk dapat melakukan persiapan dan penyesuaian masa pensiun. Beberapa hal yang dapat dipersiapkan untuk menjaga kesejahteraan di masa pensiun diantaranya menyiapkan simpanan, investasi, atau asuransi khusus untuk masa pensiun. Beberapa jenis produk keuangan untuk pensiun menurut OJK (2016a;b) adalah tabungan rencana, deposito, Program Pensiun Manfaat Pasti (PPMP), dan Program Pensiun luran Pasti (PPIP).

Menurut Walson dan Fitzsimmons (1993) dan Taft et al. (2013), kesejahteraan keuangan adalah pandangan, perasaan, dan persepsi tentang status keuangan dilihat dari posisi keuangan saat ini. Ketika sebuah keluarga memasuki fase pensiun diharapkan keluarga mempunyai kondisi kesejahteraan keuangan yang stabil. Bae, Hanna, dan Lindamood (1993) dan Malone et al. (2010) menyebutkan bahwa setiap individu memiliki penilaian yang berbeda terhadap kesejahteraan keuangan, tergantung pada tahapan siklus kehidupan. Persepsi subjektif kesejahteraan mengenai kepuasan kondisi keuangan dipengaruhi oleh literasi keuangan ditemukan pada sebuah penelitian yang melibatkan responden dengan usia lebih dari 60 tahun (Folk, Beh,\& Baranovich, 2012). Menurut Lyons et al. (2006); Martin (2007); Adam, Frimpong, dan Boadu (2017), literasi keuangan berkontribusi terhadap kesejahteraan keuangan. Individu dapat mengoptimalkan literasi keuangan yang dimiliki dengan mengatur pendapatan dan membuat perencanaan keuangan secara efektif. Kesejahteraan keuangan juga dipengaruhi oleh perencanaan pensiun, kepemilikan aset, dan juga dipengaruhi wilayah dimana responden tinggal, yaitu di perkotaan atau perdesaan (Adam, Frimpong, \& Boadu, 2017; Wolf \& Zcharias, 2006; Lersch, 2017; Otis, 2016).

Literasi keuangan menjadi bagian yang penting dalam mencapai kesejahteraan keuangan (Voydanoff, 1990; Gray, Ventis, \& Hayslip, 1992; Krause, 1991; Vosloo, Fouche, \& Barnard, 2014). Hal ini dikarenakan menurut Anderson, Baker, dan Robinson (2016); literasi keuangan yang rendah akan berdampak pada pengambilan keputusan keuangan yang hanya berdasarkan persepsi dan kurangnya keinginan untuk menerima nasihat keuangan. Hal tersebut akan berdampak pada kesejahteraan keuangan. Literasi keuangan merupakan kemampuan untuk memroses informasi terkait ekonomi, dan membuat keputusan keuangan terkait perencanaan keuangan, akumulasi kekayaan, pinjaman, dan pensiun (Lusardi \& Mitchell, 2014). Sementara, menurut Taft et al. (2013), literasi keuangan adalah kemampuan memahami dan menganalisis pilihan keuangan, rencana masa depan, serta mampu merespon dengan tepat suatu kejadian yang terkait dengan keuangan. Tingkatan literasi keuangan dibagi menjadi dua, yaitu tingkat dasar dan tingkat lanjut (Lusardi \& Mitchell, 2007). Literasi keuangan tingkat dasar mencakup pemahaman tentang perhitungan bunga bank, compound interest, inflasi, nilai uang terhadap waktu, dan money illusion. Sementara, literasi keuangan tingkat lanjut mencakup pemahaman tentang perhitungan faktor risiko, perbedaan saham dan obligasi, fungsi pasar saham, dan hubungan antara harga obligasi dan suku bunga. Literasi keuangan dipengaruhi oleh jenis kelamin, usia, status pernikahan, dan pendidikan (Agarwal et al., 2015; Lusardi \& Mitchell, 2013). Hasil penelitian Agarwal et al. (2015); Lusardi dan Mitchell (2011) menemukan bahwa laki-laki memiliki literasi keuangan yang lebih baik dibandingkan wanita; dan wanita yang sudah menikah lebih memahami keuangan dibandingkan wanita yang belum menikah.

Selain literasi keuangan, dalam proses mencapai kesejahteraan keuangan juga dibutuhkan perencanaan keuangan. Perencanaan keuangan adalah proses pengembangan dan implementasi rencana 
untuk mencapai tujuan keuangan (Garman \& Forgue, 1994). Perencanaan keuangan tidak hanya mengatur investasi uang dan menambah kekayaan, tetapi juga kewajiban kredit dan pajak, pengeluaran sehari-hari, perencanaan untuk keluarga, kepemilikan rumah, tabungan untuk dana pendidikan anakanak, tabungan untuk masa pensiun, serta melindungi diri dan keluarga dengan polis asuransi yang sesuai. Kesehatan yang lebih baik, penyesuaian masa pensiun, dan kepuasan masa pensiun merupakan hal positif dari perencanaan masa tua (Elder \& Rudolf, 1999; Noone, Stephens, \& Alpass, 2009; Noone, 2010). Perencanaan keuangan menurut Agarwal et al. (2015) dipengaruhi oleh karakteristik keluarga yaitu berupa pendidikan, besar keluarga, dan pendapatan. Menurut Amelia (2017), besarnya jumlah tanggungan keluarga memengaruhi perencanaan keuangan. Klapper dan Panos (2011) mengungkapkan bahwa literasi dan perencanaan keuangan lebih baik di perkotaan dibandingkan di perdesaan.

Tatom (2010) mengungkapkan bahwa kesejahteraan keuangan dapat diukur secara makro melalui aset materi dan aset keuangan. Aset materi didefinisikan sebagai kekayaan ekonomi, seperti tanah, bangunan, mesin, batu berharga, dan lain-lain. Aset keuangan didefinisikan sebagai klaim pendapatan yang dihasilkan oleh aset materi dalam bentuk kertas seperti saham, obligasi, reksadana, deposito, dan lain-lain. Menurut Xiao (1996), usia berpengaruh positif dengan kepemilikan aset. Selain itu, Chu et al. (2016) juga mengungkapkan bahwa literasi keuangan berpengaruh terhadap kepemilikan aset sebagai indikator kesejahteraan keuangan. Donnelly et al. (2012) menambahkan bahwa harta materi dapat memberikan kebahagiaan atau kesejahteraan dari segi keuangan. Greninger et al. (1996) menjelaskan bahwa terdapat rasio aset tertentu sehingga seseorang mencapai kesejahteraan keuangan seperti perbandingan uang tunai yang lebih besar dibandingkan biaya bulanan atau tabungan yang lebih besar daripada pendapatan kotor.

Berdasarkan uraian tersebut, berbagai penelitian yang dilakukan terkait kesejahteraan keuangan, literasi keuangan, perencanaan keuangan hari tua, dan kepemilikan aset telah dilakukan, tetapi belum ada penelitian yang mengaitkan variabel-variabel tersebut menjadi satu kesatuan khususnya pada keluarga dengan usia pensiun dan dibandingkan antara wilayah perdesaan dan perkotaan. Oleh karena itu, tujuan dari penelitian ini adalah: 1) menganalis perbedaan karakteristik individu, karakteristik keluarga, literasi keuangan, perencanaan keuangan hari tua, kepemilikan aset, dan kesejahteraan keuangan pada keluarga usia pensiun di perkotaan dan perdesaan; dan 2) menganalisis pengaruh karakteristik individu, karakteristik keluarga, literasi keuangan, perencanaan keuangan hari tua, dan kepemilikan aset terhadap kesejahteraan keuangan keluarga usia pensiun.

\section{METODE}

Penelitian ini menggunakan desain cross sectional study dengan teknik pengumpulan data melalui wawancara dengan alat bantu kuisioner yang telah teruji validitas dan reliabilitas. Lokasi penelitian dipilih secara purposive, yaitu Kota Bandar Lampung sebagai wilayah perkotaan dan Kabupaten Pringsewu sebagai wilayah perdesaan di Provinsi Lampung. Populasi penelitian ini adalah seluruh keluarga usia pensiun di Kota Bandar Lampung dan Kabupaten Pringsewu. Responden dalam penelitian ini adalah suami atau istri yang telah memasuki usia pensiun (55-65 tahun) sebanyak 120 orang yang terdiri dari 60 orang di wilayah perkotaan dan 60 orang di wilayah perdesaan.

Data primer yang dikumpulkan dalam penelitian ini meliputi: 1) karakteristik individu; 2) karakteristik keluarga; 3) literasi keuangan; 4) perencanaan keuangan hari tua; 5) kepemilikan aset, dan 6) kesejahteraan keuangan. Karakteritik individu terdiri atas usia, jenis kelamin, pendidikan, status pernikahan, dan status pekerjaan. Pendidikan dikategorikan berdasarkan tingkatan terakhir yang ditempuh responden seperti tidak sekolah, tamat SD, tamat SMP, tamat SMA, tamat Diploma, dan tamat Sarjana. Status pernikahan dikategorikan berdasarkan menikah atau tidak menikah, serta status pekerjaan dikategorikan bekerja dan tidak bekerja ketika pengambilan data dilakukan.

Karakteristik keluarga terdiri atas besar keluarga dan pendapatan keluarga. Besar keluarga diukur berdasarkan jumlah anggota keluarga dan dikategorikan menjadi tiga kategori yaitu keluarga kecil ( $\leq 4$ orang), keluarga sedang (5-7 orang), dan keluarga besar ( $\geq 7$ orang). Pendapatan keluarga per bulan dikategorikan menjadi empat kategori yaitu kurang dari sama dengan Rp1.000.000,00- Rp1.000.001,00 dan Rp5.000.000,00- Rp5.000.001,00 dan 
Rp10.000.000,00 serta lebih dari atau sama dengan Rp10.000.001,00

Literasi keuangan dalam penelitian ini adalah kemampuan dalam memahami dan menghitung pengetahuan keuangan dasar. Kuesioner literasi keuangan berjumlah delapan pertanyaan mengenai frekuensi simpanan untuk masa tua, investasi emas, tabungan untuk masa tua, perhitungan bunga bank, compound interest, inflasi, time value of money, dan money illusion yang diambil dari Lusardi dan Mitchell (2007) dan dikembangkan oleh Amelia (2017). Skor nilai yang diberikan untuk literasi keuangan adalah $0=$ salah, raguragu, dan tidak tahu serta 1=benar dengan nilai Cronbach's alpha 0,710.

Perencanaan keuangan hari tua adalah perilaku pada masalalu dalam merencanakan dan mengatur keuangan untuk masa tua. Kuesioner perencanaan keuangan hari tua dimodifikasi dari Amelia (2017) dengan pertanyaan berjumlah sebelas mengenai perilaku tabungan, investasi, dan asuransi dengan pilihan jawaban $0=$ tidak dan $1=y a$. Perencanaan keuangan hari tua dinilai berdasarkan persentase jawaban terbesar yang dipilih oleh responden berdasarkan wilayah dan total.

Kepemilikan aset adalah kepemilikan atas sumberdaya saat ini yang dapat memberikan nilai ekonomi. Kepemilikan aset berjumlah dua puluh satu pertanyaan berupa kepemilikan atas aset materi dan aset keuangan dengan pilihan jawaban $0=$ tidak dan $1=y a$. Kesejahteraan keuangan adalah persepsi dan perilaku kondisi keuangan saat ini. Kuesioner kesejahteraan keuangan terdiri dari dua belas pertanyaan dan merupakan modifikasi dari Consumer Financial Protection Bureau (CFPB) (2015). Kuesioner kesejahteraan keuangan memiliki nilai Cronbach's alpha 0,832 dengan pilihan jawaban Likert $(0=$ sangat tidak sesuai $4=$ sangat sesuai).

Data yang dikumpulkan selanjutnya diolah menggunakan program Microsoft Office Excel dan Statistical Package for Social Science (SPSS). Kemudian data diolah ke dalam skor dan dijadikan dalam bentuk indeks. Data dianalisis deskriptif (rata-rata, standar deviasi, nilai minimum dan maksimum), uji independent sample t-test, serta uji regresi linier berganda. Uji independent sample t-test dilakukan untuk membandingkan karakteristik individu dan keluarga, literasi keuangan, perencanaan keuangan hari tua, kepemilikan aset, serta kesejahteraan keuangan antara wilayah perkotaan dan perdesaan. Selain itu juga dilakukan uji regresi linier berganda untuk menganalisis faktor-faktor yang memengaruhi kesejahteraan keuangan keluarga usia pensiun.

\section{HASIL}

\section{Karakteristik Individu dan Keluarga}

Hasil penelitian menunjukkan proporsi responden laki-laki $(63,3 \%)$ lebih banyak dibandingkan perempuan (36,7\%). Perbedaan signifikan ditemukan pada tingkat pendidikan dan status bekerja antara responden yang tinggal perdesaan dan perkotaan. Tingkat pendidikan responden di perkotaan lebih tinggi dibandingkan di perdesaan. Proporsi terbesar pensiunan berdasarkan tingkat pendidikan di wilayah perkotaan adalah tamatan Sarjana $(78,3 \%)$, sementara di perdesaan adalah tamatan Sekolah Dasar (SD) yaitu sebesar $48,3 \%$ persen. Hasil memperlihatkan bahwa sebagian besar responden masih berstatus bekerja (masing-masing di perkotaan bekerja $98,3 \%$ dan di perdesaan $63,3 \%$ ). Berdasarkan besar keluarga, baik di wilayah perkotaan maupun perdesaan merupakan keluarga kecil. Hasil penelitian menunjukkan bahwa hampir tujuh perdelapan responden $(87,1 \%)$ di wilayah kota dan desa berstatus menikah. Hasil uji beda memperlihatkan bahwa besar keluarga dan status pernikahan tidak ditemukan perbedaan signifikan antara di wilayah desa dan kota.

Tabel 1 Rataan indeks literasi keuangan berdasarkan wilayah dan total

\begin{tabular}{|c|c|c|c|c|}
\hline Indikator & Kota & Desa & Desa+Kota & $p$-value \\
\hline $\begin{array}{l}\text { Frekuensi } \\
\text { simpanan } \\
\text { untuk } \\
\text { masa tua }\end{array}$ & 55,0 & 51,7 & 53,3 & 0,717 \\
\hline $\begin{array}{l}\text { Investasi } \\
\text { emas }\end{array}$ & 8,3 & 8,3 & 8,3 & 1,000 \\
\hline $\begin{array}{l}\text { Tabungan } \\
\text { masa tua }\end{array}$ & 96,7 & 55,0 & 75,8 & $0,000^{* *}$ \\
\hline Numeracy & 51,7 & 31,7 & 41,7 & $0,026^{*}$ \\
\hline $\begin{array}{l}\text { Compound } \\
\text { interest }\end{array}$ & 21,7 & 25,0 & 23,3 & 0,669 \\
\hline Inflation & 25,0 & 25,0 & 25,0 & 1,000 \\
\hline $\begin{array}{l}\text { Time value } \\
\text { of money }\end{array}$ & 53,3 & 35,0 & 44,2 & $0,044^{*}$ \\
\hline $\begin{array}{l}\text { Money } \\
\text { illusion }\end{array}$ & 60,0 & 11,0 & 35,8 & $0,000^{* *}$ \\
\hline $\begin{array}{l}\text { Rataan } \pm \\
\text { SD }\end{array}$ & $\begin{array}{r}46,4 \\
\pm 18,7\end{array}$ & $\begin{array}{c}30,4 \pm \\
18,0\end{array}$ & $38,4 \pm 19,9$ & $0,000^{* *}$ \\
\hline Min-Maks & $\begin{array}{r}0,0- \\
87,5 \\
\end{array}$ & $\begin{array}{l}0,0- \\
75,0 \\
\end{array}$ & $0,0-87,5$ & \\
\hline
\end{tabular}


Berdasarkan Upah Minimum Regional (UMR) Kota Bandar Lampung (2017) menunjukkan masih ditemukan sekitar 46,7 persen responden di wilayah perdesaan yang memiliki pendapatan kurang dari sama dengan satu juta rupiah $(\leq \mathrm{Rp} 1.000 .000,00)$

\section{Literasi Keuangan}

Hasil penelitian menunjukkan bahwa nilai total rataan indeks literasi keuangan adalah 38,4. Selain itu juga ditemukan adanya perbedaan signifikan rata-rata indeks literasi keuangan di kedua wilayah. Rata-rata indeks literasi keuangan di wilayah perkotaan $(46,4)$ lebih tinggi dibandingkan capaian responden di wilayah perdesaan $(30,4)$ seperti yang tersaji pada Tabel 1. Responden di wilayah kota telah memahami pentingnya memiliki tabungan di masa tua, akan tetapi belum memahami mengenai investasi emas. Adanya perbedaan pengetahuan mengenai tabungan masa tua dan money illusion; dengan capaian indeks responden di perkotaan lebih tinggi dibandikan di perdesaan. Hal ini menunjukkan responden di perkotaan lebih memahami tabungan. Oleh karenanya setiap bulan harus menyisihkan pendapatan untuk tabungan di masa tua dan money illusion mengenai jumlah barang yang dapat dibeli berbeda pada tahun ini dan di tahun yang akan datang. Selain itu, ditemukan perbedaan signifikan pada numeracy dan time value of money dengan capaian indeks responden di wilayah perkotaan lebih tinggi dibandingkan perdesaan. Artinya responden di perkotaan lebih paham mengenai nilai suku bunga bank dan nilai uang hari ini berbeda dengan nilai uang tiga tahun kemudian.

\section{Perencanaan Keuangan Hari Tua}

Hasil penelitian menunjukkan bahwa setengah responden $(50,0 \%)$ melakukan perencanaan keuangan hari tua. Sementara itu, berdasarkan wilayah ditemukan bahwa sebesar 73,3 persen responden di perkotaan dan 26,7 persen di perdesaan telah melakukan perencanaan keuangan hari tua; dan capaian ini berbeda signifikan antara responden di wilayah kota dan desa (Tabel 2). Dalam hal perilaku investasi juga ditemukan adanya perbedaan signifikan di kedua wilayah. Pada wilayah perkotaan sebanyak 75 persen dan wilayah perdesaan sebesar 53,3 persen responden telah melakukan investasi. Responden di perkotaan yang memiliki Asuransi Jaminan Hari Tua (JHT)/ pensiun sebesar 38,3 persen dan di perdesaan sebesar 14,4 persen dan juga ditemukan adanya perbedaan yang signifikan (Tabel 2).
Tabel 2 Persentase perencanaan keuangan hari tua berdasarkan wilayah dan total

\begin{tabular}{|c|c|c|c|c|}
\hline Kategori & $\begin{array}{l}\text { Kota } \\
(\%)\end{array}$ & $\begin{array}{c}\text { Desa } \\
(\%)\end{array}$ & $\begin{array}{c}\text { Desa+ } \\
\text { Kota(\%) }\end{array}$ & $\begin{array}{c}p- \\
\text { value }\end{array}$ \\
\hline $\begin{array}{l}\text { Melakukan } \\
\text { perencanaan } \\
\text { keuangan } \\
\text { hari tua }\end{array}$ & 73,3 & 26,7 & 50,0 & $\underset{* *}{0,000}$ \\
\hline $\begin{array}{l}\text { Melakukan } \\
\text { investasi }\end{array}$ & 75,0 & 53,3 & 64,17 & $\underset{*}{0,013}$ \\
\hline $\begin{array}{l}\text { Memiliki } \\
\text { asuransi } \\
\text { Jaminan Hari } \\
\text { Tua (JHT)/ } \\
\text { Pensiun }\end{array}$ & 38,3 & 14,4 & 21,0 & $\underset{* *}{0,000}$ \\
\hline
\end{tabular}

\section{Kepemilikan Aset}

Kepemilikan aset dalam penelitian ini dibedakan atas aset materi dan aset keuangan. Jumlah minimal jenis aset yang dimiliki oleh responden di perkotaan adalah tiga jenis dan maksimal tiga belas jenis sedangkan di perdesaan minimal aset yang dimiliki oleh responden adalah satu jenis dan maksimal sebelas jenis aset.

Aset Materi. Hasil menunjukkan bahwa secara total, persentase responden berdasarkan kepemilikan aset materi di atas 50 persen adalah responden yang memiliki rumah $(99,2 \%)$ dan motor $(78,3 \%)$. Berdasarkan wilayah, responden di perkotaan memiliki rumah $(100 \%)$, mobil $(80 \%)$, dan motor $(78,3 \%)$. Sementara di perdesaan, kepemilikan aset materi dominan adalah rumah $(98,3 \%)$ dan motor $(78,3 \%)$, selain itu responden di perdesaan memiliki ladang/sawah/kebun dengan persentase mendekati 50 persen (Tabel 3). Hasil penelitian menemukan adanya perbedan signifikan kepemilian aset materi antara responden di perkotaan dan perdesaan seperti mobil, emas, kontrakan/kosan, ternak/kolam, dan ladang/sawah/kebun. Kepemilikan mobil, emas, dan kontrakan/kosan lebih banyak dimiliki oleh responden di perkotaan sedangkan kepemilikan ternak/kolam dan ladang/sawah/kebun lebih banyak dimiliki responden di perdesaan.

Aset Keuangan. Penelitian menggambarkan secara total, kepemilikan aset keuangan yang dominan dimiliki responden adalah tabungan $(61,7 \%)$ dan asuransi kesehatan (60,8\%). Berdasarkan wilayah, aset keuangan yang dominan dimiliki responden di perkotaan adalah tabungan $(81,7 \%)$ dan asuransi kesehatan (60\%). 
Tabel 3 Persentase kepemilikan aset berdasarkan wilayah dan total

\begin{tabular}{|c|c|c|c|c|}
\hline Indikator & $\begin{array}{c}\text { Kota } \\
(\%)\end{array}$ & $\begin{array}{c}\text { Desa } \\
(\%)\end{array}$ & $\begin{array}{c}\text { Desa } \\
+ \text { Kota } \\
(\%)\end{array}$ & $p$-value \\
\hline \multicolumn{5}{|l|}{ Aset Materi } \\
\hline Rumah & 100,0 & 98,3 & 99,2 & 0,319 \\
\hline Mobil & 80,0 & 8,3 & 44,2 & $0,000^{* *}$ \\
\hline Motor & 78,3 & 78,3 & 78,3 & 1,000 \\
\hline Emas & 28,3 & 5,0 & 16,7 & $0,000^{* *}$ \\
\hline Kontrakan/kos & 28,3 & 1,7 & 15,0 & $0,000^{* *}$ \\
\hline Ternak/Kolam & 8,5 & 36,7 & 22,7 & $0,000^{* *}$ \\
\hline $\begin{array}{l}\text { Ladang/Sawah/ } \\
\text { Kebun }\end{array}$ & 28,3 & 48,3 & 38,3 & $0,024^{*}$ \\
\hline Tanah & 38,3 & 41,7 & 40,0 & 0,712 \\
\hline Kapal ikan & 1,7 & 0,0 & 0,8 & 0,319 \\
\hline \multicolumn{5}{|l|}{ Aset Keuangan } \\
\hline Tabungan & 81,7 & 41,7 & 61,7 & $0,000^{* *}$ \\
\hline Reksadana & 3,3 & 0,0 & 1,7 & 0,156 \\
\hline Saham & 1,7 & 0,0 & 0,8 & 0,319 \\
\hline Obligasi & 0,0 & 0,0 & 0,0 & 0,319 \\
\hline Mata uang asing & 3,3 & 0,0 & 1,7 & 0,156 \\
\hline Asuransi jiwa & 35,0 & 1,7 & 18,3 & $0,000^{* *}$ \\
\hline $\begin{array}{l}\text { Asuransi } \\
\text { kesehatan }\end{array}$ & 60,0 & 61,7 & 60,8 & 0,853 \\
\hline $\begin{array}{l}\text { Asuransi } \\
\text { pensiun }\end{array}$ & 45,8 & 3,3 & 24,4 & $0,000^{* *}$ \\
\hline Rata-rata \pm SD & $\begin{array}{r}6,22 \pm \\
2,14\end{array}$ & $\begin{array}{r}4,27 \pm \\
1,84\end{array}$ & $\begin{array}{r}5,24 \pm \\
2,21\end{array}$ & \\
\hline Min-Maks & $3-13$ & $1-11$ & $1-13$ & \\
\hline
\end{tabular}

Sementara itu, sebesar 45,8 persen responden di perkotaan memiliki asuransi pensiun. Pada wilayah perdesaan, responden dominan memiliki aset keuangan berupa tabungan dan asuransi kesehatan. Aset keuangan beresiko tinggi seperti reksadana dan saham tidak dimiliki oleh responden di perdesaan, sedangkan di perkotaan terdapat masingmasing 3,3 dan 1,7 persen responden yang memiliki reksadana dan saham.

Hasil uji beda memperlihatkan perbedaan signifikan ditemukan pada kepemilikan aset keuangan di kedua wilayah; yaitu bahwa kepemilikan tabungan, asuransi jiwa, dan asuransi pensiun berbeda signifikan. Ketiga jenis aset tersebut lebih banyak dimiliki oleh responden di perkotaan dibandingkan di perdesaan (Tabel 3).

\section{Kesejahteraan Keuangan}

Hasil penelitian menemukan bahwa rataan indeks kesejahteraan keuangan seluruh responden adalah sebesar 54,37. Berdasarkan wilayah, terdapat perbedaan signifikan kesejahteraan keuangan. Penelitian memperlihatkan rata-rata indeks kesejahteraan keuangan responden di wilayah perkotaan lebih tinggi dibandingkan daripada perdesaan.
Selain itu, nilai indeks kesejahteraan keuangan responden di perdesaan diketahui memiliki nilai terkecil yaitu 8,33 . Hasil ini dapat diartikan terdapat beberapa responden di perdesaan merasa tidak sejahtera dengan kondisi keuangan saat ini seperti masih merasa tidak punya uang yang cukup untuk mempersiapkan masa tua. Secara total responden baik di desa maupun di kota, terdapat indikator dengan indeks terkecil $(41,9)$ yaitu situasi keuangan saat ini belum cukup untuk memenuhi keinginan responden (Tabel 4).

Tabel 4 Rata-rata indeks kesejahteraan keuangan berdasarkan wilayah dan total

\begin{tabular}{|c|c|c|c|c|}
\hline Pernyataan & Kota & Desa & $\begin{array}{c}\text { Desa+ } \\
\text { Kota }\end{array}$ & $p$-value \\
\hline $\begin{array}{l}\text { Kesiapan dalam } \\
\text { menangani biaya } \\
\text { besar }\end{array}$ & 62,5 & 45,8 & 54,2 & $0,001^{* *}$ \\
\hline $\begin{array}{l}\text { Aman dengan } \\
\text { kondisi keuangan }\end{array}$ & 67,9 & 45,4 & 56,7 & $0,000^{* *}$ \\
\hline $\begin{array}{l}\text { Situasi keuangan } \\
\text { dapat memenuhi } \\
\text { keinginan }\end{array}$ & 47,9 & 35,8 & 41,9 & $0,011^{*}$ \\
\hline $\begin{array}{l}\text { Cara mengelola } \\
\text { uang dapat } \\
\text { menikmati hidup } \\
\text { Tidak menaalami }\end{array}$ & 74,2 & 52,9 & 63,5 & $0,000^{* *}$ \\
\hline $\begin{array}{l}\text { kesulitan } \\
\text { keuangan }\end{array}$ & 56,3 & 32,5 & 44,4 & $0,000^{* *}$ \\
\hline $\begin{array}{l}\text { Tidak khawatir } \\
\text { uang yang } \\
\text { dimiliki akan } \\
\text { habis }\end{array}$ & 54,6 & 33,3 & 44,0 & $0,000^{* *}$ \\
\hline $\begin{array}{l}\text { Cita-cita yang } \\
\text { dibuat dulu telah } \\
\text { tercapai }\end{array}$ & 68,8 & 38,3 & 53,5 & $0,000^{* *}$ \\
\hline $\begin{array}{l}\text { Pemberian } \\
\text { hadiah tidak } \\
\text { memberikan } \\
\text { tekanan } \\
\text { keuangan }\end{array}$ & 57,1 & 80,0 & 68,5 & $0,000^{* *}$ \\
\hline $\begin{array}{l}\text { Terdapat uang } \\
\text { sisa diakhir bulan } \\
\text { Mampu } \\
\text { membayar }\end{array}$ & 70,4 & 36,3 & 53,3 & $0,000^{* *}$ \\
\hline $\begin{array}{l}\text { tagihan dan } \\
\text { memenuhi } \\
\text { kebutuhan }\end{array}$ & 80,4 & 58,8 & 69,6 & $0,000^{* *}$ \\
\hline $\begin{array}{l}\text { Situasi keuangan } \\
\text { tidak } \\
\text { mengendalikan } \\
\text { hidup }\end{array}$ & 50,4 & 57,1 & 53,8 & 0,305 \\
\hline $\begin{array}{l}\text { Pada masa tua, } \\
\text { tidak merasa } \\
\text { kekurangan uang }\end{array}$ & 68,8 & 29,6 & 49,2 & $0,000^{* *}$ \\
\hline Rataan \pm & $63,26 \pm$ & $45,48 \pm$ & $54,37 \pm$ & $0,000^{\star *}$ \\
\hline $\begin{array}{l}\text { SD } \\
\text { Min-Maks }\end{array}$ & $\begin{array}{l}14,25 \\
31,25-\end{array}$ & $\begin{array}{r}18,49 \\
8,33-\end{array}$ & $\begin{array}{r}18,71 \\
8,33-\end{array}$ & $0,000^{n}$ \\
\hline
\end{tabular}

Keterangan: * signifikan pada $p<0,05$; ${ }^{* *}$ signifikan pada $p<0,01$ 
Tabel 5 Hasil uji regresi linear berganda variabel bebas terhadap kesejahteraan keuangan keluarga usia pensiun

\begin{tabular}{|c|c|c|c|}
\hline \multirow[t]{2}{*}{ Variabel } & \multicolumn{3}{|c|}{$\begin{array}{l}\text { Kesejahteraan } \\
\text { Keuangan }\end{array}$} \\
\hline & (B) & $(\beta)$ & Sig. \\
\hline Konstanta & 22,769 & & 0,005 \\
\hline $\begin{array}{l}\text { Wilayah (0: perkotaan; } \\
1 \text { : perdesaan) }\end{array}$ & 9,029 & 0,242 & $0,051^{*}$ \\
\hline $\begin{array}{l}\text { Jenis kelamin (0: laki- } \\
\text { laki; 1: perempuan) }\end{array}$ & 2,215 & 0,057 & 0,499 \\
\hline $\begin{array}{l}\text { Pendidikan (tingkat } \\
\text { sekolah) }\end{array}$ & 5,307 & 0,492 & $0,000^{* *}$ \\
\hline $\begin{array}{l}\text { Status pekerjaan ( } 0 \text { : } \\
\text { tidak bekerja; } 1 \text { : } \\
\text { bekerja) }\end{array}$ & 5,103 & 0,108 & 0,272 \\
\hline Besar keluarga (orang) & $-1,344$ & $-0,096$ & 0,274 \\
\hline $\begin{array}{l}\text { Status pernikahan ( } 0: \\
\text { duda/janda; } 1: \\
\text { berpasangan) }\end{array}$ & $-9,557$ & $-0,154$ & 0,084 \\
\hline $\begin{array}{l}\text { Pendapatan keluarga } \\
\text { (Rp000/bulan) }\end{array}$ & 0,000 & 0,139 & 0,168 \\
\hline $\begin{array}{l}\text { Literasi keuangan } \\
\text { (indeks) }\end{array}$ & 0,205 & 0,219 & $0,007^{* *}$ \\
\hline $\begin{array}{l}\text { Perencanaan keuangan } \\
\text { hari tua (indeks) }\end{array}$ & 0,195 & 0,337 & $0,001^{* *}$ \\
\hline $\begin{array}{l}\text { Kepemilikan aset } \\
\text { (jumlah jenis aset) }\end{array}$ & 1,708 & 0,203 & $0,035^{*}$ \\
\hline $\begin{array}{l}\mathrm{F} \\
\text { Adjusted } \mathrm{R}^{2} \\
\text { Sig. }\end{array}$ & & $\begin{array}{c}22,263 \\
0,349 \\
0,000^{\star *}\end{array}$ & \\
\hline Keterangan: ${ }^{*}$ nyata pada $p$ & $0,0, \pi, \pi$ & ata pada $p$ & $<0,01$ \\
\hline $\begin{array}{l}\text { Pengaruh Kara } \\
\text { Karakteristik Keluars } \\
\text { Perencanaan Keuar } \\
\text { Kepemilikan Aset te } \\
\text { Keuangan Keluarga }\end{array}$ & $\begin{array}{l}\text { teristik } \\
\text { a, Lite } \\
\text { gan } \\
\text { hadap } \\
\text { sia Per }\end{array}$ & $\begin{array}{l}\text { In } \\
\text { asi Keu } \\
\text { ari Tua } \\
\text { Kesejar } \\
\text { siun }\end{array}$ & $\begin{array}{l}\text { dividu, } \\
\text { angan, } \\
\text { dan } \\
\text { teraan }\end{array}$ \\
\hline
\end{tabular}

Hasil penelitian seperti yang tersaji pada Tabel 5 menunjukkan angka Adjusted $R$ Square sebesar 0,349 artinya bahwa variabel independen (wilayah, jenis kelamin, pendidikan, status pekerjaan, besar keluarga, status pernikahan, pendapatan keluarga, literasi keuangan, perencanaan keuangan hari tua, dan kepemilikan aset) memiliki pengaruh tehadap kesejahteraan keuangan sebesar 34,9 persen dan sisanya sebesar 65,1 persen dipengaruhi oleh variabel lain yang tidak terdapat dalam model.

Pendidikan sangat berpengaruh signifikan terhadap kesejahteraan keuangan keluarga usia pensiun $(B=5,380 ; p<0,01)$. Artinya setiap kenaikan satu tingkat pendidikan akan meningkatkan kesejahteraan keuangan keluarga usia pensiun sebesar 5,380 indeks. Selain itu, literasi keuangan $(B=0,206 ; p<0,01)$ dan perencanaan keuangan hari tua $(B=0,196$; $p<0,01)$ juga berpengaruh positif sangat signifikan terhadap kesejahteraan keuangan. Artinya setiap kenaikan satu indeks literasi keuangan dan perencanaan keuangan hari tua akan meningkatkan kesejahteraan keuangan keluarga usia pensiun sebesar 0,206 dan 0,196 satuan.

Selain itu, wilayah juga berpengaruh positif signifikan terhadap kesejahteraan keuangan $(B=9,029 ; \quad p<0,05)$. Artinya, responden di perdesaan berpeluang lebih besar untuk lebih merasa sejahtera dibandingkan responden di perkotaan. Kepemilikan aset juga berpengaruh positif signifikan terhadap kesejahteraan keuangan $(B=1,708 ; p<0,05)$. Artinya, setiap menambahnya satu jenis aset akan meningkatkan kesejahteraan keuangan sebesar 1,708 indeks.

\section{PEMBAHASAN}

Kesejahteraan keuangan di masa pensiun membutuhkan persiapan dan perencanan yang optimal. Kondisi ini dapat diwujudkan dengan tindakan perencanaan yang dapat meningkatkan pengalaman keuangan, melalui literasi keuangan (Lusardi, 2015). Kesejahteraan keuangan dapat dicapai dengan kemampuan seseorang untuk membuat keputusan keuangan, menetapkan tujuan keuangan, serta cara mengalokasikan pendapatan ke dalam pengeluaran sehari-hari dan pengadaan aset. Kesejahteraan di masa tua salah satunya dapat dicapai bila memiliki stabilitas ekonomi (Hsu, 2010). Kesejahteraan keuangan menurut Lusardi dan Mitchell (2011) dapat tercapai dengan berfungsinya literasi keuangan dan perencanaan keuangan hari tua. Penelitian ini menemukan bahwa pengaruh variabel bebas terhadap kesejahteraan keuangan keluarga dengan usia pension adalah 34,9 persen. Ada kontribusi variabel lain di luar model sebesar 65,1 persen yang dapat memengaruhi kesejahteraan keuangan; diantaranya pembuatan keputusan keuangan, personality, dan kesehatan keuangan (Bruggen et al. 2017; Donnelly at al. 2012; Gerrans et al. 2014)

Responden di perkotaan pada penelitian ini ditemukan lebih baik dalam literasi keuangan dibandingkan responden di perdesaan. Klapper dan Panos (2011) menyatakan bahwa responden perkotaan mempunyai literasi keuangan yang lebih baik dibandingkan responden di perdesaan. Kondisi ini dapat disebabkan oleh tingkat pendidikan di perdesaan yang lebih rendah dibandingkan di perkotaan, sehingga dalam memberikan jawaban responden di perdesaan kurang optimal (Befort, Nazir, \& Perri, 2012). Hal yang sama ditemukan oleh Beckman (2013); 
Agarwal (2015); Morgan dan Trinh (2017) bahwa literasi keuangan secara positif signifikan terkait dengan pendidikan; tingkat pendidikan yang lebih tinggi diindikasikan memiliki literasi keuangan yang tinggi juga. Hal yang sejalan pada penelitian ini ditemukan bahwa tingkat pendidikan responden di perkotaan lebih tinggi dibandingkan di perdesaan. Hasil uji beda ditemukan adanya perbedaan signifikan pada indikator literasi keuangan tabungan masa tua, numeracy, time value of money, dan money illusion; yang menunjukkan responden di perkotan capaiannya lebih tinggi dibandingkan responden di perdesaan. Lusardi dan Mitchell (2007); Klapper dan Panos (2011); Beckmann (2013) menemukan bahwa penduduk di perkotaan lebih baik dalam menjawab literasi keuangan dibandingkan penduduk di perdesaan terutama dalam subjek numeracy dan inflasi. Pada penelitian ini, literasi keuangan berpengaruh positif signifikan terhadap kesejahteraan keuangan. Hal ini sesuai dengan Chen, Shiho, Kiyoko (2010);) Adam, Frimpong, dan Boadu (2017) yang juga menemukan bahwa literasi keuangan berdampak positif terhadap kesejahteraan keuangan keluarga pensiun.

Hasil penelitian juga menunjukkan bahwa perencanaan keuangan hari tua berbeda signifikan antara responden perkotaan dan perdesaan. Responden di perkotaan memiliki capaian perencanaan keuangan hari tua yang lebih tinggi dibandingkan responden di perdesaan. Hal tersebut dapat terjadi karena pendidikan, pendapatan dan literasi keuangan responden di perkotaan juga lebih tinggi dibandingkan di perdesaan. Hal ini sesuai dengan Dhir (2011);Amorim, Franca, dan Valentini (2017) yang juga menemukan bahwa responden di perkotaan memiliki perencanaan keuangan yang lebih tinggi dibandingkan di perdesaan. Menurut Agarwal et al. (2015); Hsiao, Chen, dan Liao (2016), pendidikan dan pendapatan berpengaruh signifikan terhadap perencanaan keuangan. Seseorang dengan tingkat pendidikan yang lebih tinggi cenderung memiliki program pensiun (Mayer, Zick, \& Marsden,2011). Menurut Brucker dan Lappel (2013); Boisclair, Lusardi, dan Michaud (2014), kondisi ekonomi yang rendah juga mengindikasikan tidak memiliki perencanaan keuangan hari tua. Selain itu, apabila individu memiliki kemampuan literasi keuangan yang baik maka dapat melakukan perencanaan keuangan dengan detail sehingga memahami adanya resiko, membuat perencanaan tabungan, alokasi aset, serta asuransi secara berjangka. Lusardi dan Mitchell (2007); Van
Rooij et al. (2009); Clark et al. (2012); Ibrahim, Isa, dan M.,Ali (2012); Jamaludin (2012); Agnew, Bateman, dan Thorp (2013) menjelaskan bahwa literasi keuangan merupakan kunci dari perencanaan pensiun. Hasil penelitian ini juga memperlihatkan adanya pengaruh positif signifikan perencanaan keuangan hari tua terhadap kesejahteraan keuangan keluarga usia pensiun. Lusardi dan Mitchell (2011); Adam, Frimpong, dan Boadu (2017) juga menyatakan bahwa perencanaan pensiun berpengaruh signifikan terhadap kesejahteraan keuangan.

Menurut Xiao (1996), siklus kehidupan memengaruhi kepemilikan jumlah dan jenis aset. Rata-rata kepemilikan jenis aset pada responden di perkotaan dalam penelitian ini lebih banyak dibandingkan di perdesaan. Menurut Xiao (1996) dan Muskhudiani (2014), pendidikan dan pendapatan memiliki pengaruh terhadap jumlah aset yang dimiliki dan dalam penelitian initingkat pendidikan yang lebih rendah dari Sarjana, memiliki aset yang lebih sedikit. Kondisi ini juga sesuai dengan Fisher dan Weber (2004); Belen et al. (2010); Dhir (2011) yang menjelaskan bahwa pendidikan dan pendapatan di perdesaan lebih rendah dibandingkan di perkotaan sehingga jumlah jenis aset yang dimiliki responden lebih rendah di perdesaan dibandingkan di perkotaan. Menurut Behrman et al. (2013), pendidikan juga memiliki pengaruh terhadap akumulasi kekayaan melalui literasi keuangan. Literasi keuangan dapat meningkatkan kontribusi seseorang terhadap peningkatan simpanan untuk masa pensiun. Para pensiunan mempertimbangkan untuk mengelola aset walaupun memiliki literasi keuangan yang rendah (Rajola, Frigerio, \& Parrichi, 2014). Tamimi dan Kalli (2009); Mahdzan, Mohd-Any, dan Chan (2017) menyatakan bahwa peningkatan satu unit literasi keuangan meningkatkan peluang memiliki aset yang lebih beresiko. Keluarga usia pensiun di perkotaan dalam penelitian ini memiliki aset keuangan seperti reksadana dan saham. Menurut Aryeetey (2004), penduduk yang tinggal di perdesaan lebih memiliki aset yang mudah dicairkan, seperti ternak dan tanaman; berbeda dengan penduduk yang tinggal di perkotaan yang cenderung memiliki aset di perusahaan. Pada penelitian ini, kepemilikan asuransi JHT atau pensiun masih rendah. Kepemilikan asuransi JHT atau pensiun mengindikasikan bahwa seseorang memiliki tujuan pada hari tua (Amelia, 2017). Hasil memperlihatkan sebagian besar responden masih bekerja dan sedikit yang memiliki asuransi JHT atau pensiun. Helman, Copeland 
dan Vanderhei (2010), mengungkapkan bahwa hanya 69 persen pekerja yang memiliki program tunjangan pensiun.

Kesejahteraan keuangan menurut Prawitz et al. (2006) adalah penilaian dan respon terhadap kondisi keuangan. Pengukuran subjektif dari pengukuran kesejahteraan keuangan dapat membantu peneliti untuk menyelidiki persepsi dan reaksi seseorang terhadap kondisi keuangan (Norvilitis, Szablicki, \& Wilson, 2003; O'Neill et al., 2005). Hasil penelitian ini menunjukkan bahwa kesejahteraan keuangan keluarga usia pensiun berdasarkan wilayah berbeda signifikan. Rata-rata indeks kesejahteraan keuangan keluarga usia pensiun di wilayah perkotaan lebih tinggi dibandingkan di perdesaan. Hal ini dapat disebabkan oleh faktor pendidikan, pendapatan, literasi keuangan, perencanaan keuangan, dan kepemilikan aset lebih tinggi di perkotaan dibandingkan di perdesaan. Menurut Joo dan Grabble (2004); Brown dan Gray (2014), usia, status pernikahan, pendidikan terakhir, pendapatan, literasi keuangan, perilaku keuangan, dan tingkat tekanan keuangan memengaruhi kesejahteraan keuangan. Hasil penelitian ini menemukan adanya pengaruh positif signifikan wilayah perdesaan terhadap kesejahteraan keuangan keluarga. $\mathrm{Hal}$ ini dikarenakan responden di perdesaan tidak memiliki tekanan terhadap keuangan dan situasi keuangan tidak merasa mengendalikan kehidupan responden. Menurut Liu dan Guo (2008), status ekonomi dan masalah keuangan dapat menjadi batasan dalam berkemampuan untuk mandiri dan memenuhi kebutuhan untuk mencapai kesejahteraan. Sementara itu, hasil penelitian juga menunjukkan rata-rata pendapatan di perdesaan lebih rendah dibandingkan di perkotaan, tetapi responden di perdesaan lebih siap dalam menghadapi masalah keuangan.

Davey (2002) menyatakan bahwa orang-orang yang fokus terhadap hal materi, justru merasa tidak sejahtera. Menurut Hira dan Mugenda (1998), para pekerja lebih merasa optimis tentang situasi keuangan tetapi memiliki banyak kekhawatiran juga. Pada penelitian ini, responden yang bekerja lebih banyak di perkotaan dibandingkan di perdesaan. Berdasarkan pendapatan dan aset, rumah tangga pertanian merasa lebih sejahtera ekonomi dibandingkan rumah tangga nonpertanian (Katchova, 2008). Individu yang aktif menabung untuk hari tua cenderung memiliki tingkat kesiapan yang lebih tinggi dalam menghadapi hari tua (Joo \& Pauwels,
2014). Perencanaan yang baik untuk hari tua juga akan berdampak pada kepuasan pensiun dan penyesuaian yang lebih ketika masa pensiun (Schellenberg, Turcotte, \& Ram 2005; Zhu-Sams, 2004; Topa et al. 2009). Nilai literasi keuangan yang tinggi tidak berarti baik dalam hal keuangan (Atkinson \& Messy, 2012). Literasi keuangan yang lebih tinggi di perkotaan dibandingkan diperdesaan, tidak berarti menjadi kesejahteraan di perkotaan lebih tinggi. Kondisi ini disebabkan perencanaan yang digunakan sudah optimal akan tetapi belum merasa puas secara subjektif.

Menurut Hakim, Sunarti, dan Herawati (2014) pengetahuan tentang manajemen keuangan perlu diberikan kepada keluarga dengan pendapatan dan pendidikan rendah untuk mencapai kepuasan keuangan. Pekerja yang lebih tua sulit untuk mengambil keputusan penting dalam menghadapi masa pensiun karena tidak memiliki pemahaman yang cukup mengenai masalah keuangan dan investasi dasar (Lusardi \& Mitchell, 2011). Sulastri dan Hartoyo (2014) menyatakan bahwa jaminan ekonomi di masa pensiun menjadi faktor penting sehingga pensiunan yang memasuki masa lansia tidak perlu melakukan beragam strategi nafkah

Desain penelitian ini memiliki beberapa keterbatasan yang harus dipertimbangkan dalam menafsirkan hasil dan sebagai pertimbangan untuk penelitian lanjutan. Desain kuisioner kepemilikan aset yang berupa pertanyaan kepemilikan "ya" dan "tidak" tanpa mempertimbangkan nilai nyata dari aset tersebut. Menurut Aryeetey (2004), terdapat perbedaan nilai aset berdasarkan waktu dan berdasarkan kelompok orang yang membeli aset tersebut, sehingga dengan jenis aset yang sama memilliki nilai yang berbeda.

\section{SIMPULAN DAN SARAN}

Hasil penelitian menemukan bahwa tingkat pendidikan dan pendapatan keluarga dengan usia pension di perkotaan lebih tinggi dibandingkan di perdesaan. Literasi keuangan, perencanaan keuangan hari tua, kepemilikan aset, dan kesejahteraan keungan juga berbeda signifikan diantara kedua wilayah; dengan capaian lebih tinggi di wilayah perkotaan. Pendidikan, literasi keuangan, dan perencanaan keuangan hari tua berpengaruh positif signifikan terhadap kesejahteraan keuangan keluarga usia pensiun. Temuan tersbeut menegaskan bahwa semakin tinggi tingkat pendidikan, indeks literasi keuangan, dan indeks perencanaan keuangan hari tua 
akan meningkatkan indeks kesejahteraan keuangan keluarga usia pensiun.

Berdasarkan hasil penelitian, kesejahteraan keuangan pensiun dipengaruhi oleh pendidikan, literasi keuangan, perencanaan keuangan, dan kepemilikan aset, sehingga, masyarakat diharapkan dapat meningkatkan pengetahuan keuangan dan perencanaan keuangan. Pemerintah atau lembaga masyarakat terkait diharapkan partisipasinya untuk membantu masyarakat dalam literasi keuangan dan manajemen keuangan. Penelitian selanjutnya diharapkan dapat dibedakan berdasarkan jenis kelamin dan jenis pekerjaan yang lebih spesifik terkait literasi keuangan, perencanaan keuangan hari tua, kepemilikan aset, dan kesejahteraan keuangan serta kuesioner kepemilikan aset yang digunakan berdasarkan nilai rillnya.

\section{DAFTAR PUSTAKA}

Adam, A.M., Frimpong, S., Boadu, M.O. (2017). Financial literacy and financial planning: implication for financial well-being of retirees. Business and Economic Horizons. 13(2):224-236

Agarwal, S., Amromin, G., Ben-David, I., Chomsisengphet, S., Evanoff, D.D. (2015). Financial literacy and financial planning evidence from India. Journal of Housing Economics. 15, (6):1-52 Doi: http://dx.doi.org/10.1016/i.jhe.2015.0 $\underline{2.003}$

Agnew, J., Bateman, H., Thorp, S. (2013). Financial literacy and retirement planning in Australian. Australian School of Business Working Paper. 1-23

Amorim, S.M., Franca, L.H., Valentini, F. (2017). Predictors of happiness among retired from urban and rural areas in Brazil. Psicologia: Reflexão e Crítica 30:2 pp:1-8

Amelia, R. (2017). Analisis kepemilikan perencanaan keuangan hari tua pada tenaga kerja di Kota Bogor (Tesis). Institut Pertanian Bogor, Bogor, Indonesia

Anderson, A., Baker, F., Robinson, D.T. (2016). Precautionary savings, retirement planning, and misperceptions of financial literacy. Journal of Financial Economics
(2017). 1-42, doi: 10.1016/j.jfineco.2017.07.008

Aryeetey, E. (2004) Household asset choice among the rural poor in Ghana. Institute of Statiscal, Social and Economic Research. Paper presented at Workshop for the Project on Understanding Poverty in Ghana. Pp:1-23 Diambil dari https://www.ircwash.org/sites/default/ files/Aryeeta-2004-Household.pdf

Atkinson, A. Messy, F. (2012), Measuring Financial Literacy: Results of the OECD / International Network on Financial Education (INFE) Pilot Study.OECD WorkingPapers on Finance, Insurance and Private Pensions, 15, OECD Publishing, Paris. http://dx.doi.org/10.1787/5k9csfs90fr 4-en

Badan Pusat Statistik. (2017). Indeks kebahagian Indonesia tahun 2017. BPS: Indonesia

Bae, M., Hanna, S., Lindamood, S. (1993). Patterns of overspending in U.S. households. Financial Counseling and Planning, 4:11-30.

Barnard, A. (2016). Sense of coherence: A distinct perspective on financial wellbeing. Sajems NS19 (2016). 4: 647660

Beckmann, E. (2013). Financial literacy and household savings in Romania. Numeracy: 6(2):1-22DOI: http://dx.doi.org/10.5038/19364660.6.2.9

Befort, C.A., Nazir, N., Perri, M.G. (2012). Prevalence of obesity among adults from rural and urban areas of the United States: Findings from NHANES (2005-2008). The Journal of Rural Health. 28:392-397

Behrman, J.R., Mitchell, O.S., Soo, C.K., Bravo, D. (2013). How financial literacy affects household wealth accumulation. Am Econ Rev. 102(3):300-304

Belen, J., McManus, D.P., Yue, S.L., Zheng, Y.Z., Li, P.Y., Utzinger, J., ... Raso, G. (2010). Comparison of two approaches wealth via an assetbased index in rural and peri-urban settings of Hunan province, China. Emerging Themes in Epidemiology. 7(7):1-17 
Boisclair, D., Lusardi, A., Michaud, P.C. (2014). Financial literacy and retirement planning in Canada. GFLEC Working Paper Series. Pp:129

Brown, S., Gray, D. (2014). Household finances and well-being: an empirical analysis of comparison effects. Discussion Paper.8530:1-37. Paper presented at The IZA research

Brucker, E., Leppel, K. (2013). Retirement plans: Planners and Nonplanners. Education Gerontology, 39:1-11

Bruggen, E.C., Hogreve, J., Holmlund, M., Kabadayi, S., Lofgren, M. (2017). Financial well-being: A conceptualization and research agenda. Journal of Business Research.. 1-10. http://dx.doi.org/10.1016/j.jbusres.20 17.03.013

Clark, R.L., Morrill, M.S., Allen, S.G. (2012). The role of financial literacy in determining retirement plans. Economic inquiry. 50(4):1-16

Chen, J., Shiho,.,, Kiyoko, K.,(2010). Factors related to well-being among the elderly in urban China focusing on multiple roles. bioScience Trends; 4(2):61-71

Chu, Z., Wang, Z., Xiao, J.J., Zhang, W. (2016). Financial literacy, portofolio choice, and financial well-being. Social Indicators Research. DOI: 10.1007/s11205-016-1309-2

Consumer Financial Protection Bureau. (2015). Financial well-being: The goal of financial education. lowa City, IA.

Davey, J.A. (2002). Active ageing and education in mid and later life. Ageing and Society. 22(01):95-113

Donnelly, G., Iyer, R., Howell, R.T. (2012). The big five personality traits, material values, and financial well-being of self-described money managers. Journal of Economic Psychology. 33:1129-1142

Dhir, S. (2011). Trends in saving and investment pattern: a comparison or rural and urban middle class families of Ludhiana District (Tesis). Punjab Agricultural University, Ludihiana, India

Elder, H.W,, Rudolph, P.M. (1999). Does retirement planning affect the level of retirement satisfaction?. Financial Services Review. 8:117-127.

França, L.H. (2004). Attitudes towards retirement: a cross-cultural study between New Zealand and Brazilian executives (Thesis). New Zealand: The University Of Auckland

Fisher, M., Weber, B.A. (2004). Does economic vulnerability depend on place of residence? Asset poverty across Metropolitan and Nonmetropolitan areas. The review of regional studies, 34(2):137-155

Folk, J.Y., Beh, L.S., Baranovich, D.L. (2012). Financial education: determinant of retirement planning in Malaysia. Journal of Business Management and Economics. 3(2):69-78

Garman, E.T., Forgue, R.E. (1994). Personal Finance 4th Edition. USA: Houghton Mifflin Company

Gerrans, P., Speelman, C., Campitelli, G. (2014). The relation between personal financial wellness and financial wellbeing: A structural equation modelling approach. $J$ Fam Econ Iss. 35:145-160

Gray, G.R., Ventis, D.G., Hayslip, B.Jr. (1992). Socio-cognitive skills as a determinant of life satisfaction in aged persons. International Journal of Aging and Human Development. 35(3):205-218.

Greninger, S.A., Hampton, V.L., Kitt, K.A., Achacoso, J.A. (1996). Ratios and benchmarks for measuring the financial well-being of families and individuals. Financial Services Review. 5(1):57-70

Hakim, F.A., Sunarti, E., Herawati, T. (2014). Manajemen keuangan dan kepuasan keuangan istri pada keluarga dengan suami istri bekerja. Jurnal IImu Keluarga dan Konsumen. 7(3):174182

Helman, R., Copeland, C, VanDerhei, J. (2010). The 2010 RetirementConfidence Survey: Confidence Stabilizing, But Preparations Continue to Erode, Issue Brief, Employee Benefit Research Institute 340:1-45

Hershey, D.A., Henkens, K., van Dalen, H.P. (2010). Aging and financial planning for retirement: interdisciplinary 


$$
\begin{array}{llr}
\text { influences } & \text { viewed } & \begin{array}{r}
\text { through } \\
\text { crosscultural lens. }
\end{array} \\
\text { Journal of } & \text { Aging \& Hutional } \\
\text { Development, } & \text { Human } \\
\text { http://dx.doi.org/10.2190/AG.70.1.a. }
\end{array}
$$

Hira, T.K., Mugenda, O.M. (1998). Predictors of financial satisfaction: differences between retirees and non-retirees. Financial Counseling and Planning, 9(2):75-84.

Hsiao, Y.J., Chen, J.T., Liao, C.F. (2016). The relationship between financial literacy and retirement planning. Journal of Management. 33:311-335.

Hsu, H.C. (2010). Trajectory of life satisfaction and its relationship with subjective economic status and successful aging. Social Indicators Research, 99:455- 468.

Ibrahim, D., Isa, Z.M.,Ali N. (2012). Malaysian saving behaviour towards retirement planning. International Conference on Economic Marketing and Management. 28:102-105

Jamaludin, N. (2012). Individual retirement saving behaviour: evidence from Malaysia (Thesis). Edith Cowan University, Perth, Australia

Joo, S.H., Grable, J.E. (2004). An exploratory framework of the determinants of financial satisfaction. Journal of Family and Economic Issues. 25(1):25-50

Joo, S.H., Pauwels, V. (2014). Factors affecting workers' retirement confidence: A gender perspective. Journal of Financial Counceling and Planning. 13(2):1-10

Katchova, A.L. (2008). A comparison of the economic well-being of farm and nonfarm households. American Journal of Agricultural Economics, 90(3):733-747.

Klapper, L., Panos, G.A., (2011). Financial literacy and retirement planning: the Russian case. Journal of Pension Economics and Finance. 10(04):599618

Kubicek, B., Korunka, C., Raymo, J.M., Hoonakker, P. (2011). Psychological wellbeing in retirement: the effects of personal and gendered contextual resources. Journal of Occupational Health Psychology, 16:230-246. http://dx.doi.org/10.1037/a0022334.
Krause, N. (1991). Stressful events and life satisfaction among elderly men and women. Journal of Gerontology, 46 (2):584-592.

Lee, G.R., Lassey, M.L. (1980). Rural-urban differences among the elderly: economic, social, and subjective factors. Journal of Social Issue. 36(2):62-74

Lersch, P.M. (2017). Individual wealth and subjective financial well-being in marriage: resource integration or separation?. Journal of Marriage and Family. 79(5):1-13

Liu, L., Guo, Q. (2008). Life satisfaction in a sample of empty-nest elderly: a survey in the rural area of a mountainous county in China. Quality Life Research, 17:823-830.

Lusardi, A., Mitchell, O. (2007). Financial literacy and retirement planning: New Evidence from the Rand American life panel. Working Paper. 2007157:1-32

Lusardi, A. (2015). Financial literacy skills for the 21st century: Evidence from PISA. Journal of Consumer Affairs. 49 (4):639-659

Lusardi, A., Mitchell, O.S. (2011). Financial literacy and retirement planning in the United States. Journal of Pension Economics and Finances. 10:509525

Lusardi, A., Mitchell, O.S. (2013). The economic importance of financial literacy: Theory and evidence. Pension Reseacrh Council Working Paper. Philadelphia (USA)

Lusardi, A., Mitchell, O.S. (2014). The economic importance of financial literacy: Theory and evidence. Journal of Economic Literature. 52(1):5-44

Lyons, A.C., Palmer, L., Jayaratne, K.S.U., Scherpf, E. (2006). Are we making the grade? A national overview of financial education and program evaluation. The Journal of Consumer Affairs, 40(2):208-235.

Mahdzan, N.S., Mohd-Any, A.A., Chan, M.K. (2017). The influence of financial literacy, risk aversion and expectations on retirement planning and portofolio in Malaysia. Gajah 
Mada International Journal of Business. 19(3):267-288

Malone, K., Stewart, S.D., Wilson, J., Korsching, P.F. (2010). Perceptions of financial well-being among American women in diverse families. Journal of Family and Economic Issues. 31(1):63-81

Martin, M. (2007). A literature review on the effectiveness of financial education. Working Paper Series. The Federal Reserve Bank of Richmond. 07:1-27

Mayer, R.N., Zick, C.D., Marsden, M. (2011). Does calculating retirement needs boost retirement savings?. Journal of Consumer Affair. 45(2):175-200

Mukku, S.S.R., Harbishettar V., Sivakumar, P.T. (2018). Psychological morbidity after jot retirement: A review. Asian Journal of Psychiatry (2018), https://doi.org/10.1016/j.ajp.2018.08. 003

Muskhudiani, N. (2014). Estimation of household income based on asset ownership. Statistics Netherlands. Discussion Paper 2014 (01):1-25

Noone, J.H., Stephens, C., Alpass, F.M. (2009). Preretirement planning and well-being in later life: A prospective study. Research on Aging. 31(3):295317

Noone, J.H. (2010). Psychological and socioeconomic factors influencing men and women"s planning for retirement(Thesis). Massey University, New Zealand

Norvilitis, J.M., Szablicki, P.B., Wilson, S.D. (2003). Factors influencing levels of creditcard debt in college students. Journal of Applied Social Psychology. 33(5):935-947.

O'Neill, B., Sorhaindo, B., Xiao, J.J., Garman, E.T. (2005). Financially distressed consumers: Their financial practices, financial well-being, and health. Financial Counseling and Planning, 16(1):73-87.

Otis, N. (2016). Subjective well-being in China: Association with absolute, relative, and perceived economic circumtances. Soc Indic Res 132:885-905

Otoritas Jasa Keuangan [OJK]. (2016a). Seri Literasi Keuangan Segmen
Pensiunan, Hidup Sejahtera Saat Pensiun. OJK, Jakarta, Indonesia

Otoritas Jasa Keuangan [OJK]. (2016b). Seri Literasi Keuangan Segmen Pensiunan, Masa Tua Lebih Nyaman dengan Bank. OJK, Jakarta, Indonesia

Prawitz, A.D., Garman, E.T., Sorhaindo, B., O'Neill, B., Kim, J., Drentea, P. (2006). Incharge financial distress/financial well-being scale: development, administration, and score interpretation. Financial Counseling and Planning. 17(1):3450

Rajola, F., Frigerio, C., Parrichi, M. (2010). Financial well-being in active ageing. Active Ageing and Healthy Living. 6977. doi:10.3233/978-1-61499-425-169

Schellenberg, G., Turcotte, M., Ram, B. (2005). Preparing for retirement. Canadian Social Trends. 78:8-11

Schwartz, A.N. (1974). Retirement: termination or transition. Geriatrics, 29(5), 190198

Sulastri, S, Hartoyo. (2014). Pengaruh dukungan sosial dan strategi nafkah terhadap kesejahteraan subjektif keluarga usia pensiun. Jurnal IImu Keluarga dan Konsumen. 7(2):83-92

Taft, M.K., Hosein, Z.Z., Mehrizi, S.Y.T., Roshan, A. (2013). The relation between financial literacy, financial wellbeing, and financial concerns. International Journal of Business and Management. 8:63-75

Tamimi, A.H., Kalli, A.B. (2009). Financial literacy and investment decisions of UAE investors. TheJournal of Risk Finance, 10(5):500-516

Tatom, J.A. (2010). Financial wellbeing and some problems in assessing its link to financial education. Working Paper. Networks Financial Institute, Indiana State University. 03:1-16

Topa, G., Moriano, J.A., Depolo, M., Alcover, C.M.,Morales, J.F. (2009). Antecedents and consequences of retirement planning and decisionmaking: A meta-analysis and model. Journal of Vocational Behavior. 75(1):38-55

Van Rooij, Maarten, Lusardi, A., Alessie, R. (2009). Financial literacy and 
retirement planning in the Netherlands. DNB Working Papers 231. Netherlands Central Bank.

Vosloo, W., Fouche, J., Barnard, J. (2014). The relationship between financial efficacy, satisfaction with renumeration and personal financial well-being. International Business and Economic Research Journal. 13(6):1455-1470

Voydanoff, P. (1990). Economic distress and family relations: $A$ review of the eighties. Journal of Marriage and the Family. 52:1099-1115.
Walson, C.O., Fitzsimmons, V.S. (1993). Financial manager's perception of rural household economic well-being: Development and testing of a composite measure. Journal of Family and Economic Issues, 14(3):193-215.

Xiao, J.J. (1996). Effects of family income and life cycle stages on financial asset ownership. Journal of Financial Counseling and Planning. 21-30

Zhu-Sams, D. (2004) Will pre-retirement planning affect post-retirement experience?. Papers for the Western Family Economics Association. 19:51-57 